\title{
〔資料-3〕 事前アンケート回答
}

\section{キャリブレーションフリーBM 計への取組〜実践と展望}

横河電機株式会社センサ・機器事業部 P\&W システムセンター 高 野 一 志

\section{1. 現在の BM 計の仕様について}

横河電機では原理的に現在 $\mathrm{B}$ 計は 1 種類， $\mathrm{M}$ 計は 2 種類ラインナップしている。表 1 に記載した精度確 認は当社用意の標準サンプルを測定する事で定義され ている。坪量計のように複数の標準サンプルで行なう ものはばらつきで定義している。次にそれぞれのセン サについて基本的な測定原理について説明する。

\section{1 坪 量 計}

原理的には図 1 に示すように，ドセンサより照射さ
れた $\beta$ 線がセンサ間にある測定物の重量に比例して 上センサに透過する放射線量が指数関数的に減衰する ことを利用して坪量を測定する。オンラインで測定す る場合, 測定対象となる紙と同時に上下センサ間の空 気層を測定するため, 空気層測定での誤差をいかに最 小にするかがポイントになる。そのため, 測定誤差と なる空気層の量を最小にすることと, 空気層の空気密 度が変化しない構造にする必要がある。具体的にはか ねてよりロータリーシャッターを採用し上下間セン距 離を最小にすると同時に恒温化されたエアーで上下セ

表 1 測定仕様と性能

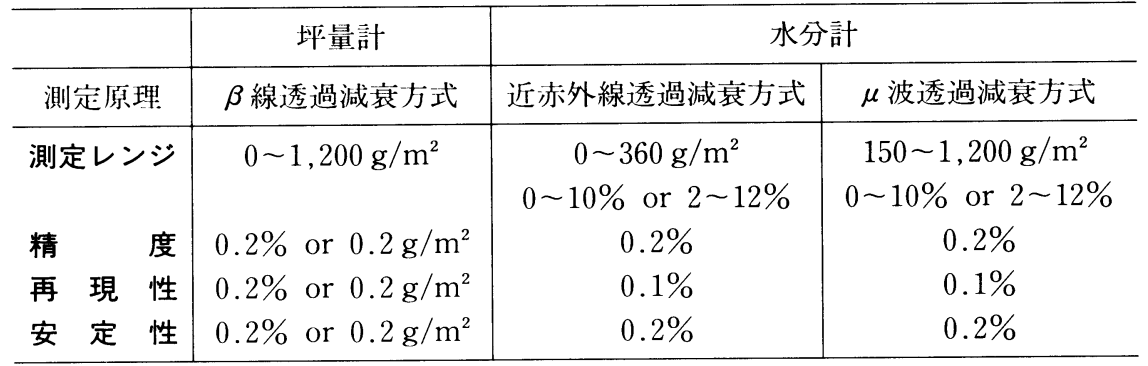

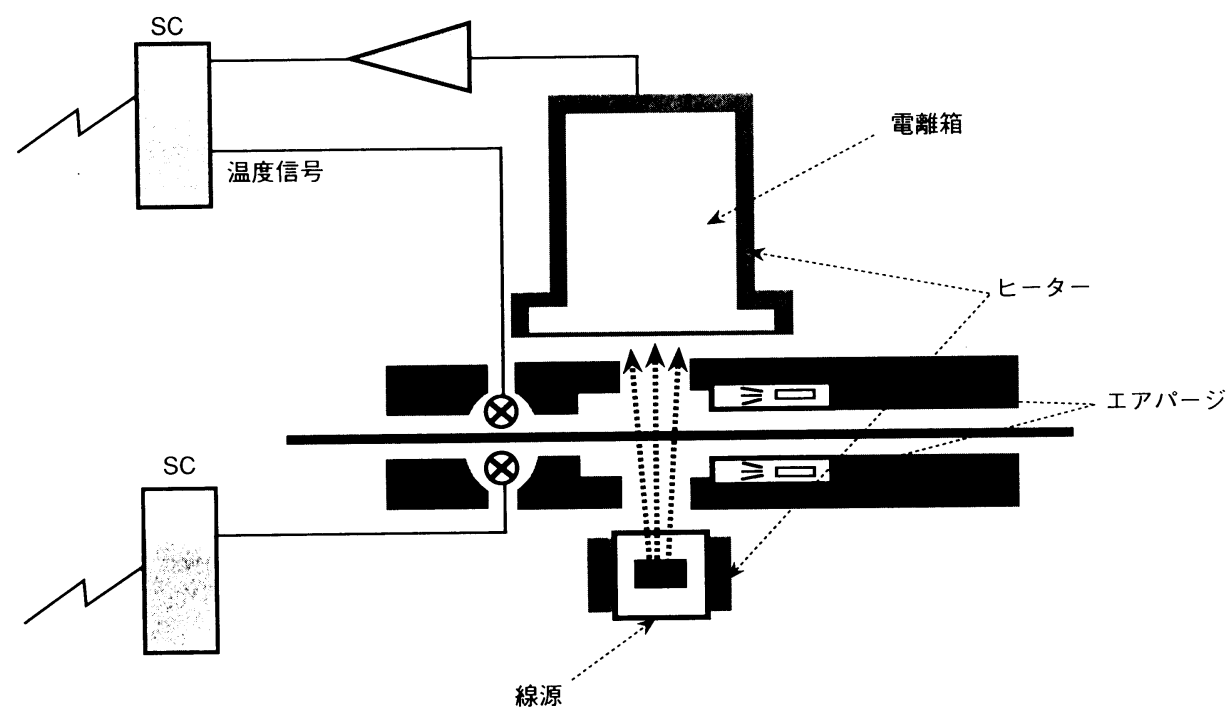

図 1 B 計 (坪量計) 


高野—志

ンサ間を満たし，一定の空気密度が維持できるように している。さらに，上下センサ間の温度を測定し空気 密度の補正を行なっている。

測定対象によって使用する放射線減は $\mathrm{Pm} / \mathrm{Kr} / \mathrm{Sr}$ と選択するがティッシュパーパーから板紙まで幅広い レンジで安定した測定が実現されている。

\section{2 水 分 計}

水分計は図 2 に示すような赤外線方式のセンサと図
3 に示すような $\mu$ 波を使用したセンサの 2 種類をライ ンナップしている。板紙に代表されるような坪量の重 い紙に対しては $\mu$ 波の水分計を, その他の一般紙に は赤外線のセンサを提案している。 $\mu$ 波水分計は紙に 照射された $\mu$ 波が紙に含まれる水分量に比例して減 衰する性質を利用して測定する。

ただ，この減衰量は紙の温度によって変化するため, 同時に測定された紙温度で補正することで精度の良い

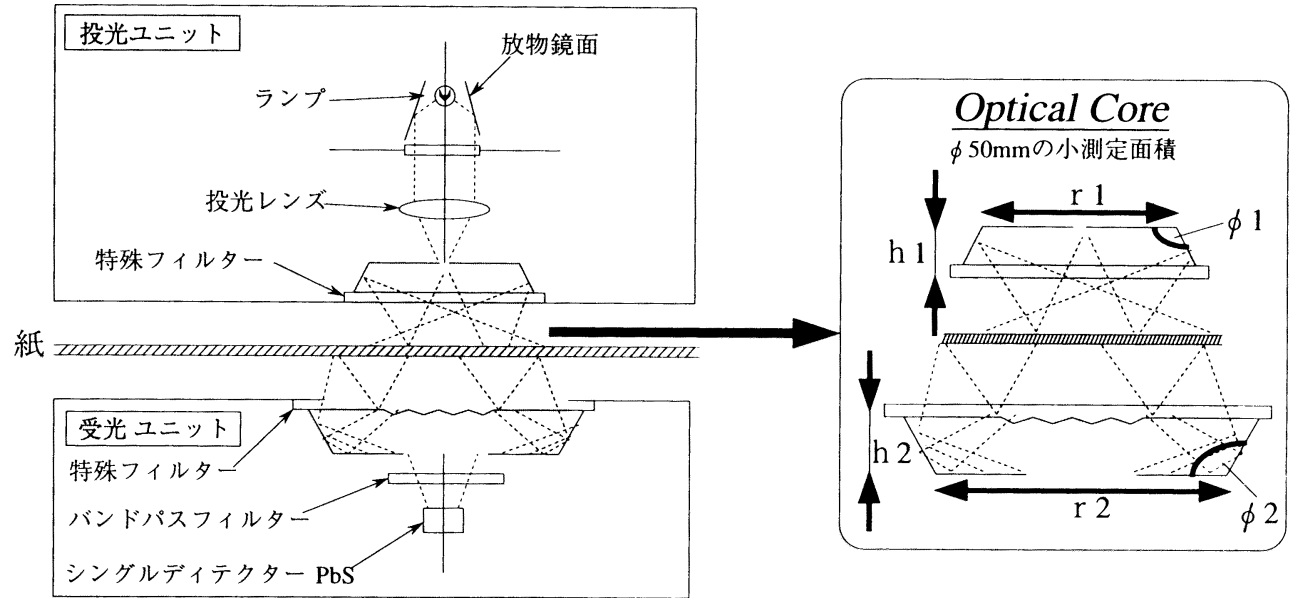

図 2 赤外線水分計

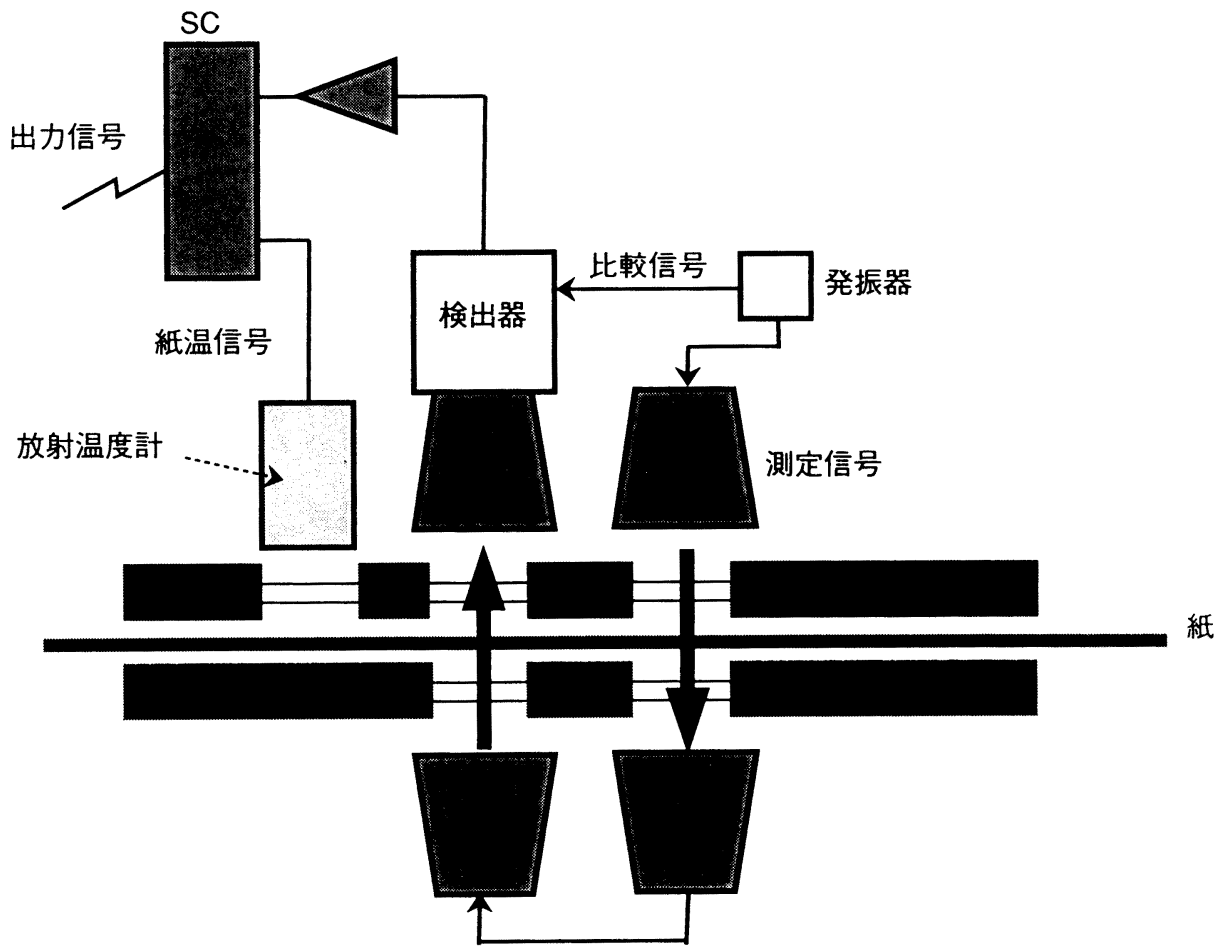

図 3 マイクロ波水分計 
測定を笑現している。また非接触の測定を実現させた ため, 接触によるピッチの污れや接触での摩擦熱に影 響されない測定が行なえる。

両センサとも測定レンジは 0 - 10\% or 2 o 12\%の 標準レンジを記載しているが坪量範囲に応じては，上 記以外の高水分率レンジも可能である。

\section{2. 最近 5 年間の発展}

各センサに対して行なってきた改良改善について説 明する。

\section{1 原理上の発展}

図 2 に示す赤外線方式の水分計は近年構造及び原理 を大幅に発展させ, 従来とは異なり水分計単独で水分 率が測定出来ると同時に, 紙質に影響されないシング ルキャリブレーションおよびセンサ交換による器差が 無いなど，理想に一歩近づいたセンサとなってきた。 原理的には近赤外線を複数使用することと新方式の 演算式を採用することで図 4 に示すように紙質に影響 を受けない測定が可能となった。さらに，測定精度の 向上と安定性を増加させることおよび板紙までの幅広 い測定レンジを確保するために集光効率のよい光学系 を開発した。従来では，測定する紙の有無で光の散乱 状態が変化するため, 測定面に堆積した紙粉の影響度 が把握出来なかった。このセンサは上下測定面に特殊
フィルターを配し，測定する紙の有無に関わらず散乱 光を照射できるようにしたため，定期的に実施する自 動校正で正確な紙粉補償が出来るようになった。

\section{2 測定環境の変化とその対応}

高効率な操業を目指して抄紙機自体で抄速のアップ, 紙幅方向制御装置の設置等が進み, $\mathrm{BM}$ 計の測定環境 も大きく変化してきた。主だった変化と対応策につい て述べる。

(1) 高温環境への対応策

環境が高温になってくると熱膨張によるフレームの 歪みが一番の問題となってくる。一部のセンサを除き, 多くのセンサが上下ぺアの方式で測定するため, フレ 一ムの上ビーム間の平行度を如何に一定に保つかが測 定精度に大きく影響する。図 5 に示すよう当社では風 性の高いモノコック構造のフレームを採用するととも にF側スタンドにベアリング機構を取付け, 熱膨張 での歪を逃がす機構にすることで温度による上下ビー ムの歪を最小にしている。

また，七ンサ自身の安定動作を確保するために，七 ンサ自身の発熱量の削減や高温化に適した部品の選択 を行なうと同時に水冷およびボルテックスチューブに よる冷却機能の提供を行ってきた。また, 赤外線水分 計のように高温な紙から発せられる赤外線自体が誤差 要因となる場合があるため, 適切な赤外線カットフィ

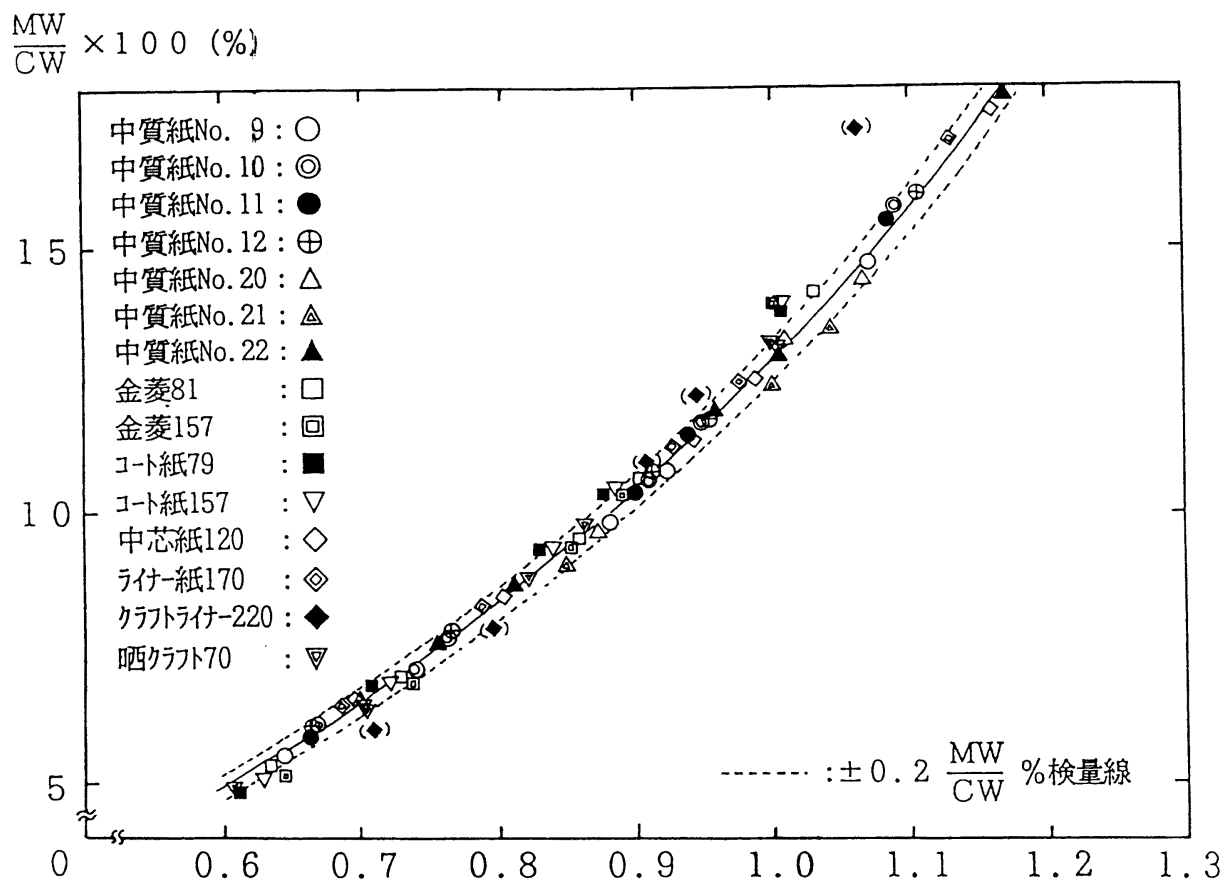

図 4 赤外線水分計測定特性 


\section{解析例}

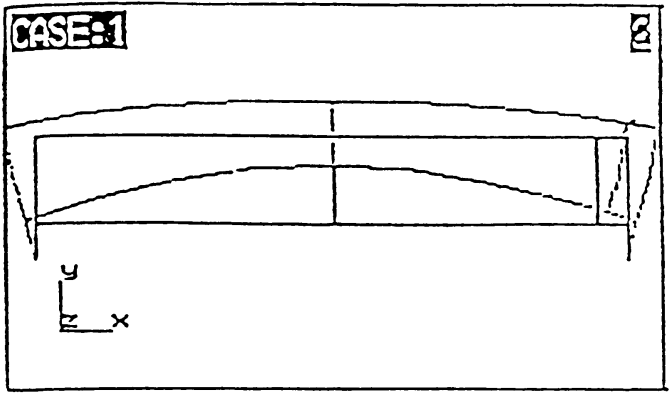

条件

設置床: $0^{\circ} \mathrm{C}$

フレーム: $+20^{\circ} \mathrm{C}$

フレーム全長： $10 \mathrm{~m}$

結果下ビーム中央の変位： $2 \mathrm{~mm}$

\section{対策}

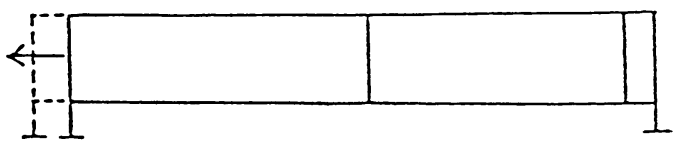

ベフリング

固定

図 5 モノコックフレームの特性

ルターを組み込み対応している。

(2) 紙 粉 対策

基本的には赤外線水分計のように紙粉が堆積しても 影響が無いセンサに改善することが一番であるが, 同 時に紙粉が堆積しないような構造が保守上は好ましい。 センサ面をフラット化し, 紙粉が体積しにくい構造に するとともに, 堆積しな紙粉が除去できるように圧縮 空気で紙粉を吹き飛ばすエアーガン機構を用意してい る。

(3) その 他

高速化による紙のバタツキ/カールも測定上問題と なってくる。そのため, 非接触でパスラインを安定化 する目的で吸着構造のパスライン規制器を採用してい る。

\section{3 ユーザからの要求仕様の変化と満足度}

精度に関するユーザ要求は従来と基本的な変化は無 く, 次の 2 点に集約できると思われる。

-より高精度/高分解能

・メンテナンスフリー (センサキャリブレーション およびハード交換に関して)

ただ，近年の抄紙機の大型/高速化にともなう傾向
で高速多点測定が必要条件になってきており，その結 果, 使用目的別に応じた精度が要求されてきている。 例えば測定絶対值の安定性/相対プロフィールの分解 能精度と, 2 種類の精度についてみても，流れ方向制 御での要求度合い, 紙幅方向での要求度合い, 品質管 理上での要求度合いや重み付けがそれぞれが異なって きている。当然，各製紙会社間の競争のなかでこれら の要求数值や要求項目は常に変化してくる。そのため, 常にユーザの満足できるものを目指して開発を行って いるが, 十二分にユーザが満足していただけるレベル には到達していないと思っている。

\section{BM 計の現状での限界と弚の理由}

\section{1 現状の方式での測定精度, 再現性, 安定性の} 限界レベル

現在の測定原理で標準サンプルを使用した条件であ れば十分に $0.05 \%$ まな $0.05 \mathrm{~g} / \mathrm{m}^{2}$ のような小数第 2 位の精度は追及可能と思われる。ただ，地合むらが ある測定物を高速で測定するオンライン测定は計器自 身の精度自体が明確に定義されておらず，今ここで設 定することが困難と思う。

\section{2 限界を越えるためのこれまでの努力と成果}

主に信号の $\mathrm{S} / \mathrm{N}$ 向上, 安定化のなめの改善とオン ラインでのノイズ除去するなめの統計演算を含む信号 処理技術の改善および原理的な改善がある。具体的に はデータのサンプリング時間を最小にし，かつデータ 伝送はディジタル伝送を使い，伝送された生信男をさ らに統計フィルターを多段に適応することなどを実施 している。

たな゙，これらの改善の目的はス夕ティックな標準サ ンプルでの精度向上でなく，オンライン測定状態で如 何にスタティックに近い精度を発揮するかに向けられ

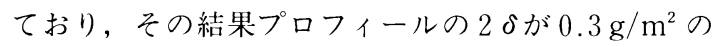
絶乾坪量プロフィールが実現している。

\section{3 今後の開発の方向と展望}

現在次のような 2 つ方向から検討している。まず はじめは要求されている測定目的とその精度を明確に することである。例えば高速多点が要求されている大 きな目的のひとつに紙幅方向プロフィール制御の効果 向上がある。少し乱暴な言い方になるかもしれないが, ここで要求される測定精度は絶対值の再現性ではなく, 微小測定面積における分解能の高い相対パターンであ る。それにひきかえ流妃方向の制御では，必要な絶対 值の再現性が重要視され, 測定周期はせいぜい数秒周 期で十分である。

このようにそれぞれの目的に応じた測定精度を実現 
させるために，1フレームに絶対坪量計と相対坪量計 の 2 台を搭載するような方向に進んで行く可能性もあ る。次に重要な点はこの精度を十分に確認できる手法 の確立である。まず，スタティックな状態で本来の計 器精度が正当に評価できる標準サンプルや校正環境, 校正条件を明確にし，その結果に基づき，オンライン 測定精度が推定できるようにすることである。

\section{4. キャリブレーションの必要性}

\section{1 スタティック・キャリブレーション}

スタティック・キャリブレーションにはシステム自 身が定期的に笑施するオート・キャリブレーションと 保守担当者が行なうスタティック・キャリブレーショ ンの 2 種類あるがここでは後者の必要性について述べ る。環境変化の対象として温湿度, 気圧变化, 紙粉堆 積などあるが，これらはオート・キャリブレーション で十分除去できる。また抄速の変化にともなうバタッ キやカールには影響を受けない構造になっており，環 境の変化でのスタティック・キャリブレーションは基 本的には不要である。また配合变化等に対しても基本 的にはスタティック・キャリブレーションを実施しな い。

ただ，測定指示の不適合が指摘されたそのトリガー が配合変化, DIP 混入率の变化添加物の変化であっ た場合，ハード的な再現性，安定性を確認する意味で スタティック・キャリブレーションを実施することが ある。部品交換を行なった場合，センサ側の部品交換 にともなう調整・確認作業の一環としてスタティッ ク・キャリブレーションを実施している。ただ，前述 した赫外線水分部のようにセンサコンプリート交換を 実施しても器差が出にくい設計をしており，このよう な場合はスタティック・キャリブレーションは実施し ていない。

\section{2 オンライン検定}

新規納入時, 測定情洗の確認をするために最低限の 銘柄について実施している。また，上記の様に測定指 示の不適命が指摘された場合その確認方法としてオン ライン検定を実施している。

\section{5. キャリブレーションについて推奨する方法と} 頻度, およびその信頼性

\section{1 スタティック・キャリブレーション}

スタティック・キャリブレーションは当社で用意し た標準サンプルおよび空気層を使用して行なう。具体 的には当社操作説明書に記載されている手順にしたが つて実施する。
実施夕イミングは故障発生時や部品交換時の突発的 タイミングがある。定期的なスタティック・キャリブ レーションの頻度は特に規定していないが，オート・ キャリブレーションのトレンド傾向を見て実施するよ うお願いしている。最近ではDIA（BM 計に関する リモートメンテナンス) でBM計のトレンドをリモ 一ト監視し，その結果に基づきスタティック・キャリ ブレーションを依頼するケースも増えている。

その信頼性は表 1 で記載した数值である。

\section{2 オンライン検定}

前述したように必要な場合は当社操作説明書に従つ て実施している。オンライン検定の信頼性は次のよう な要因に依存している。

\section{精度 $=\{($ プロセス変動 $) /$ /サプリング数 十試験手法誤差 $\}$}

図 6 にオンライン検定に近い手法で多種にわたる.上 質紙を使用して水分率検定を実施した結果を示すが， 一部では土0.3\%に入っているが全体では土 $0.5 \%$ であ る。実際のオンライン検定では図 6 にさらにプロセス 变動が加味されることと水分率のように，吸放出など 検定環境条件等の影響を考えるとその精度を明確に規 定することは非常に困難である。以上の意味でオンラ イン検定精度は土0.5\%がひとつの目安と考える。

\section{6. シングルキャリブレーションを可能にする 組成許容幅}

\section{1 坪 量 計}

坪量計の原理上:組成で影響受けるものは，紙の主成 分であるセルロースと比較して原子番号が大きい扊分 や塗工材がある。放射線検出器の改善によってその影 響度は理論上より小さくなっているが，前提条件下て の許容幅は次の通りである。

・クレイ/タルク混入率 $=60 \%$

・炭酸カルシュウム混入率 $=30 \%$

・チタン混入率 $=12 \%$

\section{2 水 分 計}

前述したように，新たに開発された赤外水分計では パルプ配合の变化に影響を受けない。

ただ，原理上単独水分率測定を行なうため，セル口 一ス重量に対する水分量を水分率として演算するため 坪量としてセルロース以外の灰分や塗工量などの比率 が多くなった場合誤差要因となる。その場合の許容幅 は次のようになる。

・(セルロース以外成分) $/$ (坪量 $)=5 \%$

ただ実際の運用では灰分，塗工量などについては自 動校正機能が用意してあるため，実用上問題になる誤 


\begin{tabular}{lll} 
高—野—— \\
\hline
\end{tabular}

\section{水分率の精度}

\section{$B M$ 指示}

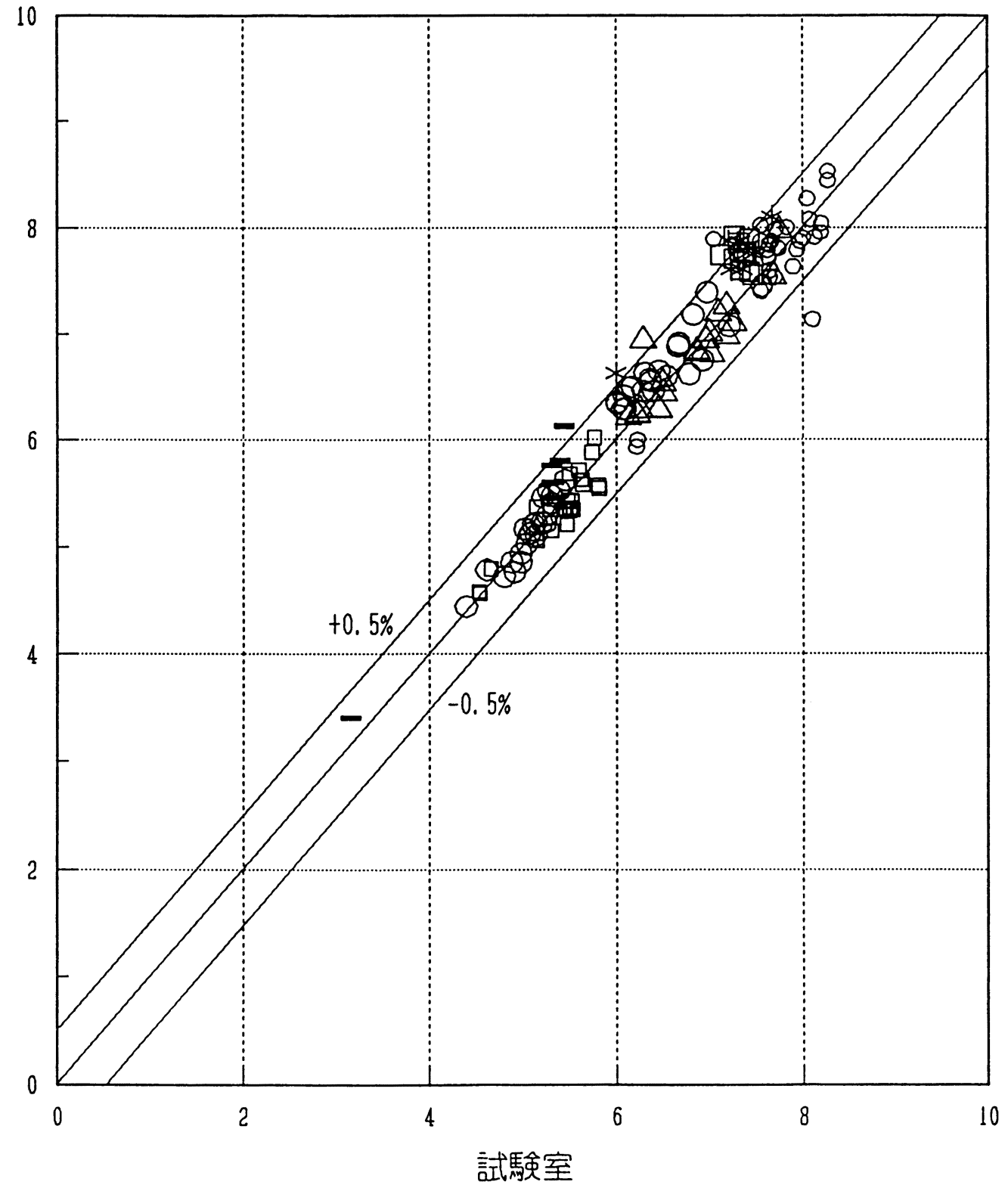

図 6 オフライン検定データ

差は発生しない。

\section{7. オンライン検定に代わる精度のチェック 方法}

オンライン検定を実施する目的は絶対伹の相関性確 認と測定感度確認に集約できると思われる。特に後者
の測定感度の確認は標準サンプルおよび測定対象とな る紙を使ったス夕ティック・キャリブレーションで対 応可能と思う。そのためオンライン検定の日的は絶对 值の確認に絞り込める。

具体的な方法としては, 看貫重量值との相関や通常 見本紙取りでの確認測定との相関の様なマクロな確認 
方法が適切と考える。もう一つの考えとして，オンラ イン測定と同様な測定原理を使用したオフライン測定 器を同一サンプルで校正し，測定対象の紙をスタティ ック・キャリブレーションする方法がある。現在, 赤 外線水分㖕でこの連用方法のテストを行なっているが, 今後十分適态可能である。

\section{BM 計の精度維持に関してユーザへの提言}

操作説明書等に記載した力法でメンテナンスを行っ ていただく事を基本的ではあるが，ユーザの方々に一 番打願いしたい。また，マク口的な手法であるが，看 貫等を使用した厓期的なデー夕比較を実施していただ きたい。

測定值の不適合が発生した場合, その要因がどこに あるか解析しやすくするためプロセス情沙等の付属デ 一夕も一緒に採取していただくのがべターである。内 容はテーマと界干異なるが, 本来, BM 計を測定機器 と考えれば公正な基準器で精度が確認できる力向に進 んでいくべきと思われる。ただ， BM 計が抄紙装置の 一部化している日本の実情からみてオンラインでの精 度評価の問題は避けられない。現在は定量的な評価が できておらず，各ユーザ独自の状況に基づいた評価基 準になっているが，日本の突情に適した統一規格につ いて検討すべきかもしれない。まず各々のユーザで要 求される紙の品質基準を明確にしていくなかで，業界
標準的な評価基準ができあがるであろうと思われる。 当然メーカーとしてこの問題に積極的に取り組んでい かなければならないが，ユーザ殿よりいただくフィー ルドデータ，ノウハウが非常に有効である。そのため にも，今後も厳しく暖かいご指導をお願いしたい。

\section{9. キャリブレーションフリーの BM 計の実現 について}

近い将来スタティックな測定においてはほぼ実現可 能であると思う。ただ，ユーザサイドから要求される 測定条件, 測定精度が年々向上する状況を考えると, 基本的にはユーザサイドで要求される操業基準, 品質 基準とのバランスであろうと思う。

本来 $\mathrm{BM}$ 計は 2 次元的平面が高速で流れる紙をそ のまま 2 次元的に測定すべきであるが, 現状ではやむ を得ず 1 時限的なサンプリング測定を行なった結果を 使って 2 次元的母集団を推定している。そのため，名 イナミックな測定精度としてはいろいろな矛盾を含む ことになる。前述したように今後は紙幅方向制御に対 する測定精度, 流れ方向制御に対する测定精度, 品質 解析で要求される測定精度各々個別に協議検討すべき であろうと思う。メーカーとしてセンサ個々の改良, 改善は当然継続して行なっていくが, 本来の要求に近 い測定方式の実現が最も大きな課題である。 